\title{
Derin ven trombozu ve pulmoner emboli
}

\section{Deep venous thrombosis and pulmonary embolus}

\author{
Soner Özcan¹, Elcil Kaya Biçer², Emin Taşkıran² \\ ${ }^{1}$ Oltu Devlet Hastanesi, Ortopedi ve Travmatoloji Kliniği, Erzurum \\ ${ }^{2}$ Ege Üniversitesi Tıp Fakültesi Hastanesi, Ortopedi ve Travmatoloji Anabilim Dalı, İzmir
}

\begin{abstract}
Venöz tromboz, venöz dolaşımda oluşan trombozların genel adıdır. Asemptomatik derin ven trombozundan ölümcül pulmoner emboliye kadar çeşitli derecelerde klinik bulgularla kendini gösterir. Total diz artroplastisi ameliyatı sonrası mortalite ve morbiditeyi arttıran önemli komplikasyonlardan biridir. Pulmoner embolinin ölümcül olabileceği ve tedavi seçeneklerinin kısıtlılığı göz önüne alındığında, önlenmesi akla daha yatkın gözükmektedir. Ideal profilakside amaç, derin ven trombozunu önlerken kanamaya bağlı komplikasyonlara neden olmamaktır. Bu yüzden risk faktörleri göz önüne alınarak uygun profilaktik ajanı seçme konusunda çeşitli kılavuzlar (American College of Chest Physicians [ACCP] ve American Academy of Orthopaedic Surgeons [AAOS] gibi kuruluşlar tarafından) geliştirilmiştir. Günümüzde venöz tromboemboli profilaksisine yönelik birçok farklı yöntem tercih edilmekte ise de bu konuda kesin kanıtlanmış veriler sınırlıdır; kullanılacak yöntemler ve süresine ilişkin tartışmalar halen devam etmektedir.
\end{abstract}

Anahtar sözcülkler: diz artroplastisi; derin ven trombozu; pulmoner emboli; komplikasyon
Venous thrombosis is a general term for thrombus formed within a vein. It includes a conditions ranging from asymptomatic deep venous thrombosis to fatal pulmonary embolus. Venous thrombosis is a significant cause of morbidity and mortality after total knee arthroplasty. Prevention of pulmonary embolus is reasonable when the limitations of treatment options considered. The ideal prophylaxis regimen should be not to cause complications related to bleeding while preventing the development of symptomatic venous thrombosis. American College of Chest Physicians (ACCP) and the American Academy of Orthopaedic Surgeons (AAOS) have developed guidelines to assist clinicians to decide appropriate prophylactic regimen. As of today, many different methods are preferred for the prophylaxis of venous thromboembolism; a consensus has not been reached regarding to the optimal compression device, the most efficacious pharmacologic agent, and ideal duration of treatment.

Key words: knee arthroplasty; deep venous thrombosis; pulmonary embolus; complication
$\mathbf{V}$ enöz tromboz (VT) venöz dolaşımda oluşan trombozların genel adıdır. En sık alt ekstremite derin venlerinde nadir olarak üst ekstremite, pelvis ve diğer venlerde görülür. VT'nin yaşamı tehdit eden en önemli klinik bulgusu pulmoner embolidir (PE). ${ }^{[1]}$ VT total diz artroplastisi (TDA) ameliyatı sonrası mortalite ve morbiditeyi arttıran önemli komplikasyonlardan biridir. ${ }^{[2]}$ Asemptomatik derin ven trombozundan (DVT) ölümcül pulmoner emboliye kadar çeşitli derecelerde klinik bulgularla kendini gösterir. ${ }^{[3]}$ TDA sonrası profilaksi yapılmayan olgularda çoğu asemptomatik olmakla birlikte DVT görülme oranı \%40-84'tür. Mekanik ve farmakolojik yöntemlerle profilaksi uygulanan hastalardaysa asemptomatik DVT görülme oranı $\% 5,1$, semptomatik DVT oranı \%0,4 olarak belirtilmektedir. ${ }^{[4,5]}$ Bir başka çalışmada, TDA sonrası PE'ye bağlı 90 günlük mortalite $\% 0,08$ olarak bulunmuştur. ${ }^{[6]}$

Sağaltımı oldukça zor ve yüksek maliyetli olan PE'nin önlenmesi akla daha yatkın gözükmektedir. Son yıllarda venöz tromboemboli (VTE) profilaksisi konusunda yoğun olarak çalışılmaktadır. Buna karşın ideal profilaksi seçimi halen tartışmalı bir konudur. Tartışmanın ortaya çıkmasında çok sayıda etken gözlenebilir. Hasta topluluklarının homojen olmaması, asemptomatik olgular, tanısal yöntemlerin yetersizliği ve ticari etkenler bunlardan bazılarıdır. Bir araştırmada, bu konuda yapılmış olan çalışmaların \%80'inin ticari şirketler

- İletişim adresi: Prof. Dr. Emin Taşkıran, Ege Üniversitesi Tıp Fakültesi Hastanesi, Ortopedi ve Travmatoloji Anabilim Dalı, İzmir Tel: 0532 - 3771385 e-posta: emintaskiran1961@gmail.com

- Geliș tarihi: 19 Aralık 2018 Kabul tarihi: 19 Aralık 2018 
tarafindan finanse edildiği gösterilmiştir. Bu durum, nesnel veri değerlendirmesini etkileyebilecek ve özellikle ilaç profilaksisi lehine yanlı sonuçlara yol açabilecek niteliktedir. Yine de, bu çalışmalar VTE profilaksisindeki bilgi birikimine katkı sağlamıştır. ${ }^{[7]}$ Iddeal profilakside amaç DVT'yi önlerken kanamaya bağıı komplikasyonlara neden olmamaktır. ${ }^{[8]}$ Bu yüzden risk faktörleri göz önüne alınarak uygun profilaktik ajanı seçme konusunda çeşitli kılavuzlar geliştirilmiştir.

\section{ETIYOLOJi VE PATOFIZYOLOJi}

VTE gelişimini kolaylaştıran üç temel patogenetik mekanizma Virchow tarafindan yaklaşık 150 yıl önce tanımlanmıştır ve halen kabul görmektedir. Kan akımının yavaşlaması (staz), damar duvarında hasar (endotel hasarı) ve hiperkoagülabilite, Virchow üçlüsü (triadı) olarak tanımlanmaktadır. ${ }^{[9]}$

TDA'da altta yatan patofizyolojik mekanizmalardan biri femoral kanal açılması sırasında venöz sisteme yağ dokusu ve kemik iliği elemanlarının girmesine bağlı oluşan sistemik hiperkoagülabilite durumudur. Total diz ve kalça artroplastisi sonrası bilateral venogram yapılan hastalarda, ameliyat edilmeyen tarafla karşılaştırıldığında, ameliyat edilen ekstremitede \%10-15 oranında DVT tespit edilmiştir. ${ }^{10]}$ TDA sonrası DVT geçiren bir olgu grubunda, ameliyattan sonraki ilk 24 saat içinde olguların \%70'inde kontrast venografi pozitif bulunmuş; diğer \%30'luk kısımda ise tetkik 24 saatten sonra pozitifleşmiştir. ${ }^{[11]} \mathrm{Bu}$ durum, pıhtılaşma sürecinin ameliyat sırasında aktive olduğuna işaret etmektedir. Turnike açıldıktan hemen sonra kanda trombin kompleksinde artış gözlenmektedir. Bu bulgu, turnike açılmasından hemen sonra yapılan transözofageal ekokardiyografide saptanan pozitif ekojenik embolik fenomen ile doğrulanmıştır. ${ }^{[12]}$

Virchow üçlüsünün bir diğer bileşeni olan endotel hasarı, TDA sırasında bacağın hiperfleksiyona alınması ve tibianın retraktör ile öne disloke edilmesiyle oluşabilir. Ayrıca, bu manipülasyon sırasında popliteal venlerdeki obstrüksiyon ve bacağın uzun süre hareketsiz tutulması Virchow üçlüsünün üçüncü bileşeni olan venöz göllenmeye (staz) neden olmaktadır. ${ }^{[9]}$

\section{RISK FAKTÖRLERI}

\section{Yaş}

Kırk yaşından itibaren VTE riski artmaya başlamakta ve bu yaştan itibaren her 10 yılda risk iki katına çıkmaktadır. ${ }^{[13]}$ Oger ve ark., VTE insidansını araştırdıkları bir çalışmada 75 yaş ve üzerinde VTE görülme oranını \%1 olarak bulmuşlardır. ${ }^{[14]}$ Yaş diğer risk faktörlerinden bağımsız olarak VTE riskini arttırmaktadır.

\section{Genetik Faktörler}

Tromboemboli riskini arttıran genetik faktörler genel olarak trombofili olarak adlandırılmaktadır. Bu konuda en çok Faktör V Leiden mutasyonu üzerinde çalışımıştır. Bunun yanı sıra, antitrombin 3 (AT3), protein C ve protein $\mathrm{S}$ eksikliği tromboemboli riskini arttıran genetik faktörler arasında yer almaktadır. Özellikle genç olgularda (50 yaş altı) görülen VTE'lerde bu genetik mutasyonların altta yatabileceği göz önünde bulundurulmalı ve bunlar araştırılmalıdır. ${ }^{[15]}$

\section{İmmobilizasyonun Etkisi}

İmmobilizasyonun VTE risk faktörü olarak etkisi özellikle hemiplejik hastalarla ilgili yapılan çalışmalarda gösterilmiştir. Warlow ve ark., serebrovasküler olay geçirmiş hastaları inceledikleri çalışmalarında, asemptomatik DVT oranını paralize olmuş ekstremitelerde $\% 60$, paralize olmamış ekstremitelerde ise $\% 7$ olarak bulmuşlardır. ${ }^{[16]}$ İmmobilizasyon özellikle eşlik eden diğer risk faktörleri varlığında VTE gelişim riskini arttırmaktadır.

\section{Oral Kontraseptif ve Hormon Kullanımı}

Bu tür ilaçlarda VTE riskini arttıran, içeriklerinde bulunan östrojendir. Östrojen, bazı pıhtılaşma faktörlerinin (Faktör II, VII ve X) plazma düzeylerini arttırırken AT3'ün plazma düzeyini düşürerek koagülasyona yatkınlık yaratır. Östrojenin bu etkisi doz bağımlıdır. VTE riski ilaç kullanılmaya başlandıktan sonraki dört ay içinde artmakta, ilaç kullanımı sonlandırıldık$\tan$ üç ay sonrasına kadar devam etmektedir. ${ }^{[17]}$

\section{Geçirilmiş VTE Öyküsü}

Geçirilmiş VTE öyküsü diğer risk faktörlerinden bağımız olarak VTE gelişimi için güçlü bir risk faktörüdür. ${ }^{[18]}$ VTE öyküsü olan olgularda yüksek riskli bir işlem sonrasında VTE gelişim riski, VTE geçirmemiş olanlara göre sekiz kat fazla bulunmuştur. ${ }^{[19]}$

\section{Diğer Faktörler}

\section{Obezite}

Obezitenin (vücut kitle endeksinin $\geq 30 \mathrm{~kg} / \mathrm{m}^{2}$ olması) VTE ile ilişkisinin incelendiği SIRIUS çalışmasında, obezitenin DVT riskini iki kat arttırdığı gösterilmiştir. ${ }^{[19]}$ Bununla birlikte obezitenin tek başına risk faktörü olmadığı, özellikle eşlik eden diğer risk faktörleri varlığında VTE gelişim riskini arttırdığı bildirilmektedir. ${ }^{[20,21]}$

\section{Malignensi}

Benzer şekilde malignensinin de VTE riskine direkt etkisi bulunmamakla birlikte diğer risk faktörleriyle 
birlikteliği halinde riski iki-üç kat arttırdığı gösterilmiştir. Tedaviye kemoterapi eklenmesi bu riski daha da arttırmaktadır. ${ }^{[22]}$

\section{Sigara}

Sigara kullanımı tek başına bağımsız bir risk faktörü olmamakla birlikte özellikle oral kontraseptif ilaç kullanan kadınlarda VTE riskini arttırmaktadır. Yapılan bir çalışmada, oral kontraseptif kullanan ve sigara içmeyen grupta VTE riski 3,9 kat artmışken bu oran sigara içen grupta 8,8 kattır. ${ }^{[23]}$

\section{Anestezi tipi}

TDA uygulanan hastalarda, anestezi tipinin VTE gelişimi üzerine olan etkisinin araştırıldığı çalışmalarda genel anesteziye oranla nöraksiyel (spinal ya da epidural) anestezinin DVT riskini azaltmada etkili olduğu gösterilmiştir. ${ }^{[24]}$ DVT riskindeki bu azalmanın olası mekanizması; epidural anestezi sonrası oluşan sempatik blokajın alt ekstremitede vazodilastasyona, artmış arteriyel akıma ve venöz boşalmaya neden olarak venöz göllenmeyi azaltmasıdır. ${ }^{25]}$ Yapılan randomize kontrollü çalışmalarda, kullanılan antikoagülan profilaksisinden bağımsız olarak spinal ya da epidural anestezinin genel anesteziye oranla venografik DVT insidansını \%50 oranında azalttığı gösterilmiştir. ${ }^{[26]}$ Bölgesel anestezinin intraoperatif trombogenez üzerine doğrudan etkisi gösterilememiş olmakla birlikte vazodilatasyon sayesinde fibrinoliziste artış saptanmıştır. Bunlara ek olarak genel anesteziye oranla AT3 düzeylerinde düşmenin daha az olduğu tespit edilmiştir. ${ }^{[27]}$

\section{Turnike kullanımı}

Turnike kullanımı ameliyat edilen bacakta kan akımını keserek kuru bir cerrahi alan, daha iyi bir görüş ve muhtemelen kemik çimento arası daha iyi bir tutunma sağladığından çoğu cerrah tarafından tercih edilmektedir. Turnike kullanımı bacakta venöz göllenmeye neden olarak pretrombotik bir durum yaratır; fakat Aglietti ve ark.'nın yaptığı randomize kontrollü bir çalışmada, turnike kullanımının venöz göllenmeye yol açmasının yanı sıra fibrinolizisi de arttırdığı, sonuç olarak turnike kullanılmayan hastalara göre daha az tromboz geliştiği gösterilmiştir. ${ }^{[28]}$ Fukuda ve ark. tarafindan yapılmış bir başka çalışmada, turnike kullanımının DVT insidansını arttırmadığı bildirilmiştir. ${ }^{[29]}$

\section{Cerrahi girişimle ilgili özellikler}

Daha önceden söz edildiği gibi ameliyat sırasında tibial komponentin yerleştirilmesi sırasında dizin hiperfleksiyona zorlanması, arteriyel ve venöz damar çeperlerine hasar verebilmektedir. Daha çok ameliyat öncesi hareket kısıtlılığı fazla olan olgularda beklenmelidir. Bu işlemin yapılmaması ya da zorunluluk durumunda kısa tutulması önerilir.

\section{TANI}

\section{Derin Ven Trombozu}

DVT, ortopedik bir cerrah deneyimi ile bakıldığında şiş, kızarık ve ağrılı bir bacak olarak karşımıza gelir. DVT'de fizik muayene bulguları her zaman çok net değildir. Fizik muayene bulgusu olarak en sık bacakta kızarıklık, şişme, Homans belirtisi (ayağa dorsifleksiyon yaptırıldığında ağrı oluşması) ve Pratt testi'nde pozitiflik (baldırı sıkma ve sıvazlama ile ağıı olması) tespit edilir. Bu bulgular, tam tıkanıklık yapan DVT sonrası saptanmaktadır. Özellikle artroplasti sonrası oluşan DVT'nin büyük çoğunluğu tam tıkanıklık yapmadığı için klinik olarak tanı koymak zordur. Tüm DVT olgularının ancak \%1'i klinik olarak bulgu verir.

DVT'de klinik belirtilere dayanarak tanı koymak güvenilir bir yöntem değildir. DVT belirti ve bulguları olan hastaların ancak \%25'inde tanı testlerle doğrulanabilmektedir. Tanıyı kesinleştirmek için klinik risk skorlaması yapılmakta ve pıhtı yıkım ürünlerini gösteren D-dimer veya Doppler ultrasonografi (US), kontrastlı venografi, bilgisayarlı tomografi (BT) ve manyetik rezonans (MR) görüntüleme gibi incelemelerin yapılması gerekmektedir. Tablo 1'de DVT tanısında kullanılabilecek risk skorlama sistemi yer almaktadır. ${ }^{[30]}$ Şekil 1'de de basitleştirilmiş bir DVT tanı algoritması verilmiştir. [31]

D-dimer testinin negatif olması DVT tanısını yüksek doğruluk oranıyla dışlar; fakat testin pozitif olması aynı şekilde tanı koydurmaz; çünkü kanser, inflamasyon, yakın zamanda geçirilmiş cerrahi girişim, karaciğer hastalığı gibi birçok durumda D-dimer değerleri yükselir. ${ }^{[32]}$

Alt ekstremitede DVT tanısı için en iyi yöntem girişimsel bir işlem olmasına rağmen venografidir. Hem distal (bacak venleri) hem de proksimal (popliteal, femoral, iliak venler) trombüs radyografik olarak dolma defekti şeklinde görülür (Şekil 2). Venografinin doğruluk oranı bacak venlerinde $\% 97$, iliak venlerde $\% 70$ olarak bulunmuştur. ${ }^{[32]}$

Venografinin en önemli komplikasyonu \%3 oranında DVT'ye neden olabilmesidir. Girişimsel bir işlem olması, kullanılan kontrast maddenin alerjik reaksiyona yol açabilmesi ve DVT oluşturma riski nedeniyle ilk basamak görüntüleme yöntemi olarak kullanılmamaktadır. Günümüzde girişimsel olmaması, tekrarlanabilir olması, hasta tarafindan kolay kabul edilmesi ve venografiye göre daha ucuz bir yöntem olması nedeniyle en sık kullanılan görüntüleme yöntemi renkli Doppler US'dir. DVT şüphesi olan hastalarda ilk tercih edilecek görüntüleme yöntemidir. Genel olarak proksimal DVT duyarlılığı \%96, distal DVT duyarlılığı \%44 ve DVT'deki özgüllüğü ortalama \%93 olarak bulunmuştur. ${ }^{[33]}$ Dupleks US için ise bu değerler sırasıyla \%97, \%71 ve \%93'tür. 
Tablo 1. Derin ven trombozu tanısında klinik risk skorlaması (Wells)

Klinik özellikler

Aktif kanser (tedavi sürüyor, son 6 ay içinde tedavi uygulanmış, palyatif tedavi yapılıyor)

Paralizi, parezi veya alt ekstremitelerde atel uygulaması

Üç günden uzun süreyle yatağa bağımlılık, son 4 hafta içinde majör cerrahi girişim

Derin ven sistemi üzerinde lokalize hassasiyet

Tüm bacakta şişme

Tuberositas tibia $10 \mathrm{~cm}$ altında yapılan ölçümde asemptomatik bacağa kıyasla $3 \mathrm{~cm}$ 'den fazla artış

Gode bırakan ödem (semptomatik bacakta daha fazla)

Derin ven trombozu öyküsü

Kollateral yüzeyel venler (non-variköz)

Derin ven trombozu tanısından daha fazla olası alternatif tanı

uan

Risk değerlendirmesi

Skor

Derin ven trombozu olasılığı

Düşük

Orta

Yüksek

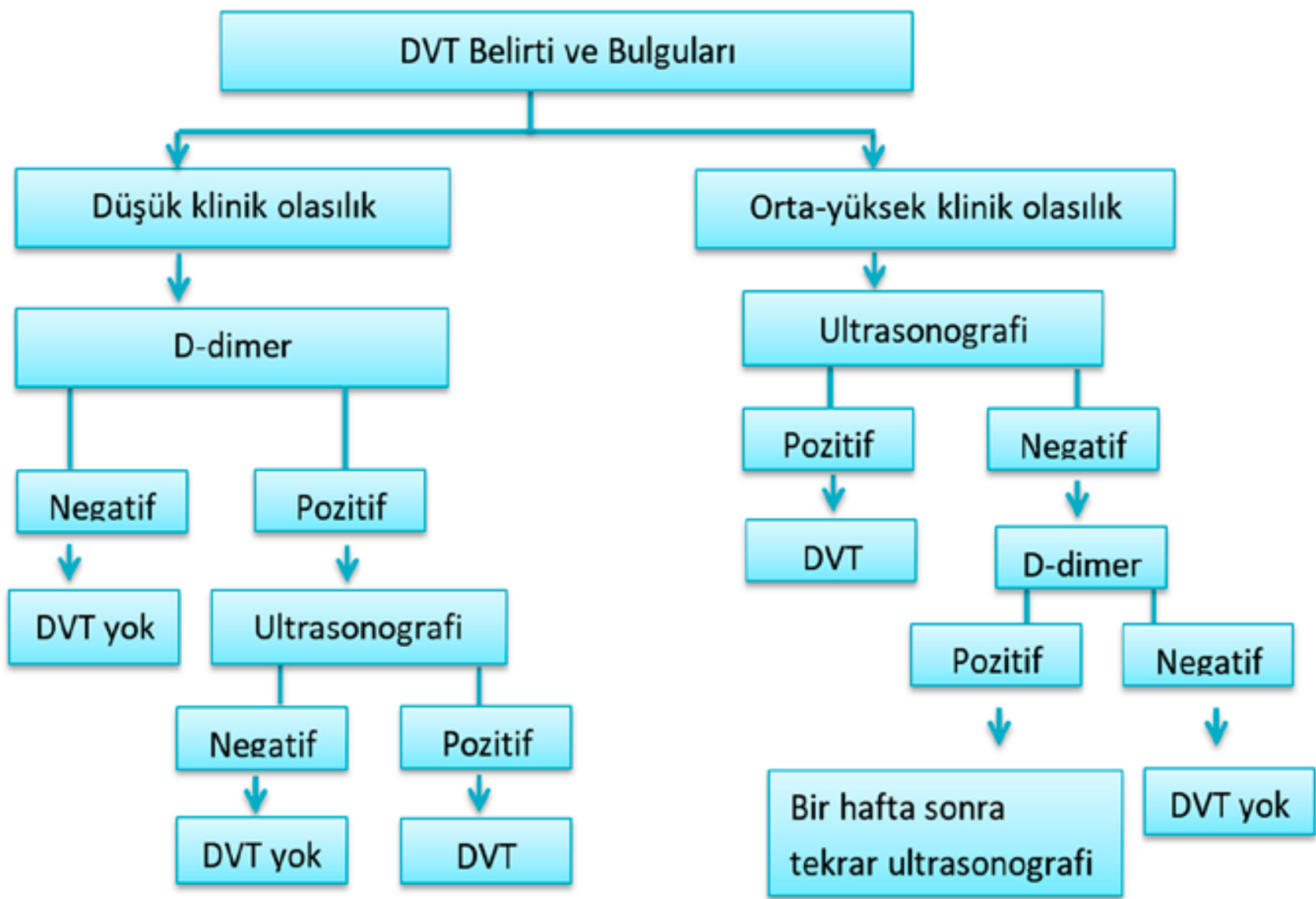

Şekil 1. DVT şüphesi olan olgularda tanı algoritması. 


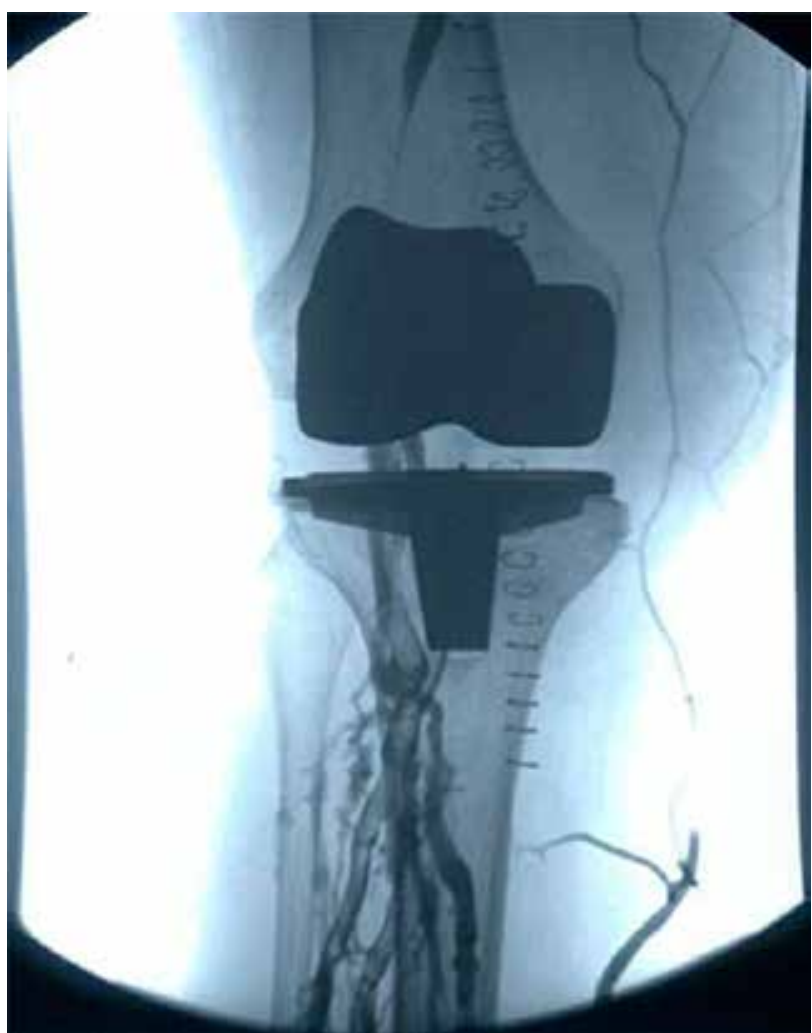

Şekil 2. Sağ TDA sonrasında yapılan venografide popliteal vende trombüs.

Yüksek çözünürlüklü indirekt multidedektör BT venografi hızlı uygulanabilmesi, \%100 duyarlılığa, \%96,6 özgüllüğe sahip olması nedeniyle son yıllarda hem DVT hem de PE tanısı koymada en etkili yöntem olarak nitelendirilmekte ve kullanılmaktadır. ${ }^{[34]}$

Üzerinde çalışmalar yapılan başka bir görüntüleme yöntemi ise MR direkt trombüs görüntülemedir. Bu görüntüleme yönteminin DVT için duyarlılığı \%95, özgüllüğü \%91 olarak bulunmuştur. ${ }^{[35]}$

\section{Pulmoner Emboli}

DVT'nin bir komplikasyonu olarak da nitelendirilebilen PE, genellikle ani başlayan dispne, takipne, taşikardi ve göğüs ağrısı gibi bulgularla karakterizedir ve bu bulgular sadece bu hastalığa özgü değildir. O yüzden tanıya giden yol klinik kuşku ile başlar. Başlangıç semptom ve bulguların yanında hastayı risk faktörleri açısından da değerlendirmek gereklidir. Klinik bulguların özgül olmaması ve verilecek antikoagülan tedavinin yüksek kanama riski taşıması en kısa sürede tanının doğrulanmasını ya da dışlanmasını gerektirir. Bu amaçla klinik tanı olasılığını daha da güçlendirmek için klinik olası skorlama sistemi geliştirilmiştir. Geçerliliği kanıtlanmış bu skorlama sistemine Tablo 2'de yer verilmiştir. ${ }^{[36]}$

Fibrin yıkım ürünü olan D-dimer düzeyi tanıda başvurulan laboratuvar testidir. Fakat DVT tanısında olduğu gibi negatif saptanması PE olasılığının düşük olduğunu göstermekle birlikte pozitif saptanmasının $\mathrm{PE}$ tanısında bir yeri yoktur.

Görüntüleme yöntemi olarak ilk başvurulacak yöntem akciğer grafisidir. Kardiyopulmoner hastalığı bulunmayan PE'li hastaların \%20-40'ında akciğer grafisi normaldir. Akciğer grafisinin normal olması PE olasılığını dışlamaz.

Ventilasyon/perfüzyon sintigrafisi, PE kuşkusu taşıyan hastalarda güvenilir bir tanı testidir. Yüksek olasılıklı sintigrafi sonuçları tanıyı doğrulamak için yeterli iken orta ve düşük olasılıklı sonuç çıkması durumunda tanıyı doğrulamak için ileri inceleme yapılması gerekir. Bu amaçla BT anjiyografi yapılabilir. Eğer tek detektörlü BT ile inceleme yapılırsa BT'nin normal olması tek başına PE'yi dışlamaz; alt ekstremite US ile proksimal trombüsün negatif bulunması da gerekir. Ancak, aynı durumda çok detektörlü BT kullanılması tek başına tanıyı dışlayabilir. Pulmoner anjiyografi PE tanısında altın standart olmakla birlikte girişimsel bir işlem olması nedeniyle ancak diğer yöntemlerle kesin tanı konulamadığı durumlarda kullanılmaktadır (Şekil 3). ${ }^{[36]}$

\section{PROFILAKSI \\ (ÖNLEME VE KORUNMA YÖNTEMLERI)}

Profilaksinin amacı olguları DVT ve DVT komplikasyonları olan $\mathrm{PE}$, pulmoner hipertansiyon ve posttrombotik sendrom oluşumundan korumaktır. ABD'de yapılan çalışmalar 1986 yılında artroplasti ameliyatlarının ancak \%75'inde DVT profilaksisi için ilaç kullanılırken, 1992 yılında bu oranın \%92'ye yükseldiğini göstermektedir. ${ }^{[37]}$ Günümüzde ise profilaksi uygulamamak malpraktis olarak kabul edilmektedir.

VTE profilaksisinde temel olarak kabul edilen iki kılavuz mevcuttur. Bunlardan biri Amerikan Gögüs Hastalıkları Doktorları Birliği (American College of Chest Physicians -ACCP) tarafından verilen, temel amacı daha çok VTE profilaksisi olan ve kanamaya bağlı komplikasyonları ikinci planda tutarak daha güçlü antikoagülanların kullanılmasını öneren bir kılavuzdur. ${ }^{[3]}$ Diğeriyse, Amerikan Ortopedik Cerrahlar Akademisi (American Academy of Orthopaedic Surgeons -AAOS) tarafindan yayımlanan, hastaların risk faktörlerine göre sınıflandırıldığı, düşük riskli hastalara daha zayıf antikoagülanlarla profilaksi öneren ve etkin profilaksi yanında, profilaksiye bağlı kanama komplikasyonlarını da göz önünde bulunduran bir 
Tablo 2. Wells pulmoner embolizm klinik olasılık skorlaması

\begin{tabular}{lc}
\hline Bulgu & Puan \\
\hline Derin ven trombozu semptom ve bulguları varlı̆̆ı & 3,0 \\
Alternatif tanı olasılığı düşük & 3,0 \\
Taşikardi ( >100/dakika) & 1,5 \\
Son dört hafta içinde hareket kısıtlılı̆ı veya cerrahi öyküsü & 1,5 \\
Daha önce derin ven trombozu veya pulmoner embolizm öyküsü & 1,5 \\
Hemoptizi & 1,0 \\
Kanser varlığı & 1,0 \\
\hline Risk değerlendirmesi & $<2,0$ \\
\hline Düşük klinik olasılık & Toplam skor (puan) \\
Orta klinik olasılık & $2,0-6,0$ \\
Yüksek klinik olasılık & $>6,0$ \\
VEYA & $>4,0$ \\
Pulmoner embolizm klinik olasılı̆̆ı zayıf & $>4,0$ \\
Pulmoner embolizm klinik olasılığı kuvvetli &
\end{tabular}

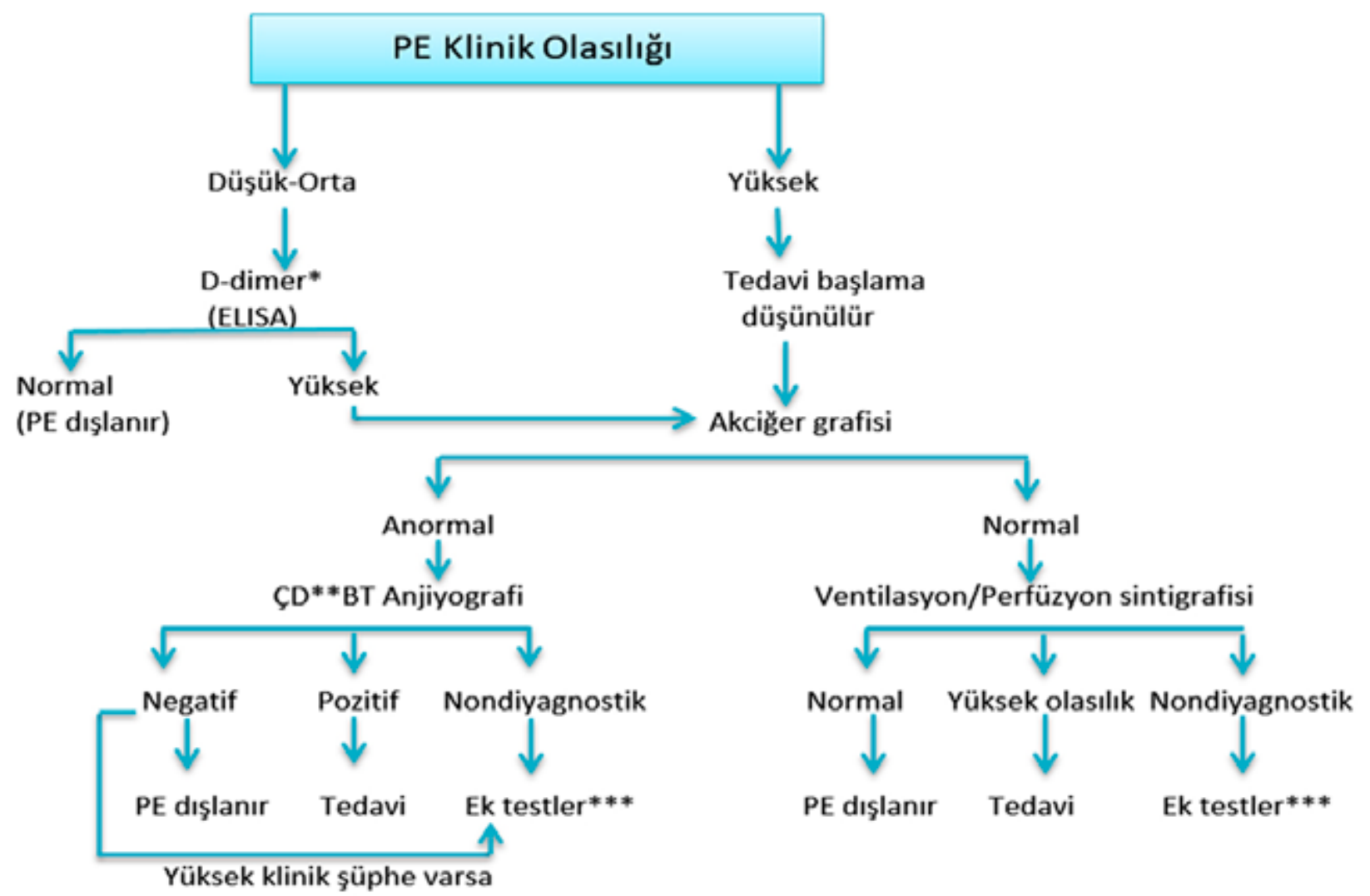

* Klinik olasılık düşük ise orta duyarlılıklı testler (Latex, simple-RED) kullanılabilir.

** Çoklu detektörlü.

*** Alt ekstremite kompresyon ultrasonografisi, seri ultrasonografi, pulmoner anjiyografi.

Türk Toraks Derneği Pulmoner Tromboembolizm Tanı ve Tedavi Uzlaşı Raporundan alınmıştır.

Şekil 3. PE şüphesi olan olgularda tanı algoritması. 
kılavuzdur. ${ }^{[38]}$ Hastalarda profilaksi seçimi yapılırken diğer komorbiditeleri de göz önünde bulundurmak gerekmektedir.

Profilaktik yöntemler farmakolojik ajanlarla yapılan kimyasal profilaksi ve mekanik profilaksi olarak ikiye ayrılmaktadır. ACCP kılavuzuna göre, yöntemden bağımsız olarak en az 10-14 gün süreyle tromboz profilaksisi uygulanmalıdır. DVT profilaksisi için kullanılan ajanlar; düşük molekül ağırlıklı heparin (DMAH), standart heparin (SH), fondaparinuks (indirekt Faktör Xa inhibitörü), apiksaban ve rivoraksaban (direkt Faktör Xa inhibitörü), dabigatran (direkt trombin inhibitörü), warfarin (K vitamini antagonisti), asetil salisilik asit (ASA) ve aralıklı pnömatik kompresyon cihazıdır (APKC). APKC dışındakiler 1B düzeyinde (güçlü öneri - orta kalitede kanıt) önerilirken APKC 1C (güçlü öneri - düşük kalitede kanıt) olarak önerilmektedir (Tablo 3). ${ }^{[3]}$ ASA, bir önceki kılavuzda kullanılacak ilaçlar arasında bulunmazken son ACCP kılavuzunda düzey $1 \mathrm{C}$ olarak önerilmektedir. Ayrıca ilk defa bu kılavuzda, profilaktik tedavilere bağlı olarak karşılaşılan artmış kanama riskine yer verilmiştir.
AAOS kılavuzuna göre TDA ameliyatı olacak hastalar DVT gelişimi için risk grubunda yer almaktadır; ancak profilaksinin süresi ve kullanılacak yöntem için sabit bir rejim önerilmemiş ve hastaya özgü olması gerektiği belirtilmiştir. ${ }^{[38]}$

Her iki kılavuzda da geçirilmiş VTE öyküsü olan ya da hiperkoagülabiliteye yol açan risk faktörlerinin birine sahip olan hastalar yüksek risk grubu olarak kabul edilmektedir. Bu hasta grubunda güçlü antikoagülan ilaçların kullanılması önerilmekle birlikte, ilaç dozunun iyi ayarlanması ve profilaksi süresinin uzatılması gerektiği vurgulanmıştır.

\section{Mekanik Profilaksi}

Mekanik profilakside amaç alt ekstremiteye kompresyon yaparak venöz stazın azaltılması ve fibrinolizisin arttırılmasıdır. Kullanılan yöntemler arasında erken mobilizasyon, antitromboembolik kompresyon çorapları (varis çorabı) ve APKC sayılabilir. Bu yöntemlerde kanama komplikasyonuyla nadiren karşılaşılmakta ve dikkat edildiğinde neredeyse hiç komplikasyon olmamaktadır. Ancak, en sık karşılaşılan sorun hasta uyumudur.

Tablo 3. Kılavuzlarda kullanılan öneri dereceleri

\begin{tabular}{|c|c|c|}
\hline Destekleyen kanıtların metodolojik gücü & Sonuç & Öneri derecesi (Grade) \\
\hline Önemli kısıtlılı̆ıı olmayan RKÇ’ler & $\begin{array}{l}\text { Çoğu koşulda çoğu hastaya } \\
\text { uygulanabilir. }\end{array}$ & $\begin{array}{l}\text { Güçlü öneri-1A } \\
\text { Yüksek kalitede kanıt }\end{array}$ \\
\hline $\begin{array}{l}\text { Önemli kısıtlılıkları bulunan RKÇ’ler } \\
\text { (tutarsız sonuçlar, metodolojik sorunlar) } \\
\text { veya gözlemsel çalışmalardan önemli miktarda kanıt }\end{array}$ & $\begin{array}{l}\text { Çoğu hastaya uygulanma olasılığı } \\
\text { yüksek. }\end{array}$ & $\begin{array}{l}\text { Güçlü öneri-1B } \\
\text { Orta kalitede kanıt }\end{array}$ \\
\hline $\begin{array}{l}\text { Gözlemsel çalışmalar, sistematik olmayan } \\
\text { klinik çalışmalar }\end{array}$ & $\begin{array}{l}\text { Daha güçlü kanıtlar bulunduğunda } \\
\text { değişebilir. }\end{array}$ & $\begin{array}{l}\text { Güçlü öneri-1C } \\
\text { Düşük kalitede kanıt }\end{array}$ \\
\hline $\begin{array}{l}\text { Önemli kısıtlılığı olmayan } \\
\text { RKÇ’ler }\end{array}$ & $\begin{array}{l}\text { En iyi seçim hastanın koşullarına veya sosyal değerlere } \\
\text { göre değişebilir. }\end{array}$ & $\begin{array}{l}\text { Zayıf öneri-2A } \\
\text { Yüksek kalitede kanıt }\end{array}$ \\
\hline $\begin{array}{l}\text { Önemli kısıtlılıkları bulunan RKÇ’ler } \\
\text { (tutarsız sonuçlar, metodolojik sorunlar) } \\
\text { veya gözlemsel çalışmalardan önemli miktarda kanıt }\end{array}$ & $\begin{array}{l}\text { Bazı koşullardaki bazı alternatif yaklaşımlarda } \\
\text { bulunulması daha iyi olabilir. }\end{array}$ & $\begin{array}{l}\text { Zayıf öneri-2B } \\
\text { Orta kalitede kanıt }\end{array}$ \\
\hline Gözlemsel çalışmalar & $\begin{array}{l}\text { Diğer alternatifler eşit derecede } \\
\text { mantıklı olabilir. }\end{array}$ & $\begin{array}{l}\text { Zayıf öneri-2C } \\
\text { Düşük kalitede kanıt }\end{array}$ \\
\hline
\end{tabular}




\section{Erken mobilizasyon ve yatak içi egzersiz}

Lassen ve ark., erken ameliyat sonrası mobilizasyonun DVT inisidansını düşürdüğünü göstermişlerdir. Sadece bir dakika ayak hareketinin ortalama 30 dakika süreyle ayak venöz dolaşımını arttırdığı gösterilmiştir. ${ }^{[39]}$ Erken hareket DVT'nin önlenmesinde basit, güvenilir ve komplikasyonsuz bir yöntemdir.

\section{Antitromboembolik çoraplar (kompresyon, varis çorapları)}

Bu çorapların kullanımı femoral vende kan akımını 1,5 kat arttırır; damar çapını küçülterek venöz dönüşü arttırır ve venöz göllenmeyi azaltır. Diz altı uygulanan çorapların diz üstü uygulananlar kadar etkili olduğu ve hastalar tarafından daha iyi tolere edildiği gösterilmiştir. ${ }^{[40]} \mathrm{Bu}$ çorapların kullanımının artroplasti ameliyatları sonrası DVT oranını \%54'ten \%20 'ye düşürdüğü öne sürülmektedir.[41]

\section{Pnömatik kompresyon cihazı}

Bu cihazların kullanılması venöz damar çapını basınçla daraltarak hem venöz kanı proksimale doğru pompalar hem de kan akım hızını arttırır. Ek olarak kompresyon sayesinde fibrinolitik sistem uyarılmış olur. ${ }^{[42]}$

Hamilton ve ark.'nın 3000 total diz protezi olgusu üzerinde yapmış oldukları geriye dönük bir çalışmada, bilinen hiçbir risk faktörü olmayan hastalara iki hafta diz üstü varis çorabı, yatış süresince ayak pompası ve erken mobilizasyon uygulanmıştır; DVT oranının \%2,1, PE'nin \%1,4 olduğu ve bir olguda fatal PE geliştiği bildirilmiştir. ${ }^{[43]}$

Pierce ve ark., yaptıkları bir meta-analizde mekanik profilaksi amacıyla kullanılan kompresyon çoraplarını, diz üstü ve diz altı kompresyon cihazlarıyla ayak pompalarını klinik etkinlik, hasta uyumu, kullanım kolaylığı açısından karşılaştırmışlardır. Kompresyon çoraplarının kan akımında standart, ideal bir gradiyent oluşturma konusunda güvenli bulunmadığını; bu nedenle, profilakside tek başına kullanılmalarının önerilmediği sonucuna varmışlardır. Kompresyon cihazlarının birbirinden farklı ilkeler temelinde çalışan, çeşitli modellerinin olduğu ve maliyetinin modellere göre değişebildiği belirtilmektedir. Diz üstü cihazlar, diz altı olanlar ya da ayak pompaları kadar etkin bulunmamıştır. Taşınabilir cihazların kullanım kolaylığı ve hasta uyumunu arttırması üzerinde durulmaktadır. ${ }^{[44]}$

Synder ve ark., yaptıkları randomize kontrollü klinik çalışmalarında, TDA uygulanan hastalarda ASA kullanımıyla beraber APKC kullanım süresini araştırmışlardır. Hastalara ameliyat sonrası dönemde taşınabilir kompresyon cihazıyla mekanik profilaksi ve üç hafta boyunca günde iki kez 325 mg ASA verilmiştir.
Çalışma grubunda mekanik profilaksi ameliyat sonrası altı hafta, kontrol grubundaysa yalnızca hastanede yatış süresince uygulanmış; mekanik profilaksiyi altı hafta süreyle kullanan grupta asemptomatik DVT'ye rastlanmazken, bu oran kontrol grubunda $\% 23$ olarak saptanmıştır. ${ }^{[45]}$

Yalnızca kompresyon cihazı kullanımının DVT profilaksisindeki etkinliğini, kemoprofilaksi ajanları ile karşılaştıran bir çalışmayla karşılaşılmamıştır. Çok merkezli bir çalışmada, TDA hastalarına ameliyat sonrası en az 10 gün süreyle (cerrahın tercihine göre ASA ile birlikte ya da tek başına) taşınabilir kompresyon cihazıyla mekanik profilaksi uygulanmış ve 90 günlük izlemde olguların \%1,6'sında semptomatik DVT, \%0,13'ünde PE geliştiği saptanmıştır; bu oranlar literatürde yer bulmuş olan warfarin, enoksaparin, rivaroksaban ve dabigatran gibi kemoprofilaktik ajanlarla elde edilen korunma başarısıyla karşılaştırıldığında, mekanik kompresyonun rivaroksaban dışındaki tüm ajanlarla benzer korunma sağladığı sonucuna varılmışır. Rivaroksabanın sağladığı korunmaysa daha üstün bulunmuştur. ${ }^{[46]}$ Taşınabilir kompresyon cihazının ameliyat sonrası kanama riski üzerine etkisinin değerlendirildiği total kalça protezinde profilaksi çalışmasında, düşük moleküler ağırlıklı heparine göre anlamlı derecede düşük oranda kanamayla karşılaşılmış olduğu bildirilmiş ve TDA'da mekanik kompresyon cihazıyla profilaksinin de benzer oranda düşük kanamayla ilişkili olması gerektiği çıkarımı yazarlar tarafından yapılmıştır. ${ }^{[47,48]}$

ACCP, mekanik profilakside APKC kullanılmasını önermektedir. Hasta tarafından taşınabilir ve pilli olması, aynı zamanda hasta üzerinde en az 18 saat çalıştığını gözlemleyebilecek bir takip sistemi olması önerilmektedir.

Mevcut kanıtlar, diz altı aralıklı pnömatik kompresyon cihazının uzun süre kullanılmasının asemptomatik DVT'nin azaltılmasında en etkili mekanik profilaksi yöntemi olduğunu desteklemektedir. ${ }^{[44]}$

\section{Kimyasal Profilaksi}

\section{Warfarin (K vitamini antagonistleri)}

$K$ vitamini antagonisti olan warfarin, koagülasyon kaskadındaki Faktör II, VII, IX ve X'u inaktive ederek fibrin oluşumunu engeller. Aynı zamanda yine $\mathrm{K}$ vitaminine bağımlı olan ve fibrinolitik etkiye sahip protein C ve S'nin de aktifleşememesine yol açar; fakat bu etki, faktör aktifleşmesinin inhibisyonuna göre daha erken ortaya çıktığı için hastada geçici bir pıhtılaşmaya yatkınlık durumu gelişir. Bu nedenle, warfarin tedavisine başlandıktan sonra koagülasyon faktörleri üzerine olan etkisi ortaya çıkana kadar hasta eş zamanlı olarak heparinize edilir. 
Warfarinin antikoagülan etkileri geri dönüşümlüdür ve takibi INR (International Normalization Rate) ölçümü ile yapılır. Güvenli kullanım aralığı oldukça dardır. TDA sonrası warfarin profilaksisi alan 8800 hasta üzerinde yapılmış güncel bir çalışmada, VTE görülme oranının $\% 1,12$ olduğu saptanmıştır. ${ }^{[49]}$ Warfarin fibrinolitik etkiye de sahip olduğundan kanama, yara yerinde uzamış akıntı ve yara yeri enfeksiyonu gibi yan etkileri vardır. Bu çalışmada bu etkiye bağlı komplikasyonlar sırayla \%3, $\% 0,38$ ve $\% 0,46$ olarak bulunmuştur. Bir diğer dezavantajı, ilaç-ilaç ve ilaç-besin etkileşiminin fazla olmasıdır; bu etkileşimler doz ayarlamasını zorlaştırmaktadır. ${ }^{[50]}$

Diğer kemoprofilaksi ajanlarının bulunmasıyla warfarin kullanımında son yıllarda düşüş gözlenmektedir. TDA sonrası warfarin kullanımı ile ilgili yapılan 18.000 hastanın dahil edildiği bir çalışmada 2007-2015 yılları arasında warfarin kullanımında yıllık \%3'lük bir düşüş olduğu saptanmıştır. ${ }^{[50]}$

\section{Heparin ve türevi kimyasal ajanlar}

Etkisini dolaşımdaki AT 3'e bağlanıp onu aktif hale getirerek gösterir. Aktive AT3 aktif halde olan enzimatik pıhtılaşma faktörlerini (Faktör II (trombin), Faktör IX, X, XI ve XII) inhibe eder. Standart heparin (SH) (fraksiyone olmamış yüksek molekül ağırlıklı heparin), düşük molekül ağırlıklı heparin (DMAH) ve sentetik pentasakkarit (fondaparinuks) olmak üzere kullanımda olan üç formu vardır.

1. Standart heparinler (fraksiyone olmamış heparin): SH'ler, 1970'lerin sonu 1980'li yılların başında yoğun olarak kullanılmıştır; fakat majör kanama oranında artışa yol açmaları ve PE'ye bağı ölüm oranını anlamlı düzeyde azaltmamaları nedeniyle günümüzde pek tercih edilmemektedir. ${ }^{[3]}$

2. Düşük molekül ağırlıklı heparinler (DMAH): Düşük molekül ağırlıklı heparinler SH'nin depolimerizasyonu ile elde edilir ve ortalama molekül ağırlıkları 5000 Da'dır. SH'den farkları Faktör X üzerine daha fazla, trombin üzerineyse daha az etkili olmalarıdır. Antitrombin aktivitesi olmaması nedeniyle SH'ye göre kanamaya yol açma riskleri daha düşüktür.

TDA sonrası DMAH uygulanan hastalarda DVT oranları \%50 oranında azalmaktadır; 10-14 günlük kısa süreli ya da 27-35 günlük uzatılmış profilaksiyle kanama riskinde belirgin artış gözlenmemektedir. ${ }^{[51]}$

En sık tercih edilen DMAH enoksaparin olup günde $40 \mathrm{mg}$ subkütan enjeksiyon şeklinde uygulanmaktadır. ${ }^{[3]}$ Profilaktik enoksaparin uygulamasına ameliyattan 12 saat sonra başlanması; yüksek risk grubundaki hastalarda günde iki kez kullanılması önerilmektedir. ${ }^{[3]}$ Böbrek yetmezliği olanlarda kreatinin klirensi $30 \mathrm{ml} / \mathrm{dk}^{\prime} \mathrm{n} ı$ altında ise enoksaparin dozu $30 \mathrm{mg} /$ güne düşürülmelidir. Obez hastalarda doz ayarlamasının sabit doz uygulamasına üstünlüğü gösterilememiştir. ${ }^{[52]}$

AAOS kılavuzu herhangi bir farmakolojik ajan için bir öneride bulunmazken; ACCP, VTE profilaksisinde DMAH'leri temel ilaç olarak belirlemiştir. ${ }^{[3]}$ Bu ilaçların ortopedik cerrahi hastaların tromboprofilaksisinde etkili ve güvenli olduklarını gösteren çok sayıda ve güçlü kanıtlar içeren çalışma bulunmaktadır. ${ }^{[3]}$ Bununla birlikte DMAH kullanan hastalarda yara yeri enfeksiyonu, sistemik kanama bulguları, yara yeri problemleri gibi komplikasyonlar bildirilmiştir. ${ }^{[50]}$

Bir meta-analizde, 56.730 hastayı içeren 45 randomize kontrollü çalışma incelenmiş ve TDA uygulanan hastalarda tromboprofilakside DMAH, apiksaban, dabigatran, rivaroksaban ve warfarin kullanımı ile kemoprofilaksi kullanılmaması yara yerinde kanama riski bakımından karşılaştırılmıştır. Bu risk, DMAH kullananlarda kemoprofilaksi yapılmayanlara göre 2,32 kat, warfarin kullananlara göre 1,54 kat, dabigatrana göre 4,38 kat, apiksabana göre 1,27 kat artmış olarak bulunmuştur. Rivaroksabanla DMAH'ler arasında yara yerinde kanama riski bakımından fark saptanmamıştır. ${ }^{[53]}$

Bala ve ark., TDA uygulanan hastalarda kanama komplikasyonları yönünden ASA ile DMAH'yi karşılaştırdıkları çalışmalarında, DMAH grubunda transfüzyon gereksinimini daha yüksek saptarlarken, 90 günlük izlemde kanama komplikasyonları açısından önemli bir fark gözlemlememişlerdir. ${ }^{[50]}$

Cafri ve ark. yaptıkları bir çalışmada, TDA uygulanan hastalarda ASA, DMAH, fondaparinuks ve warfarini etkinlik ve güvenlik açısından karşılaştırmışlardır. Toplam 30.000 hastanın 90 günlük takibinde DMAH, kanama komplikasyonları açısından ASA kadar güvenli bulunmuştur. ${ }^{[49]}$

3. Fondaparinuks: Fondaparinuks, sentetik bir antitrombotiktir. Faktör Xa inhibisyonu yapar, Faktör Ila üzerine etkisi yoktur. AT3'e bağlanarak AT3'ün Faktör Xa'yı inhibe edici etkisini arttırmış olur.

Subkütan olarak günde 2,5 mg kullanılmaktadır. DMAH'lerin kullanımına benzer şekilde obez hastalarda doz ayarlamasına gerek yoktur. Uygulamaya ameliyattan 6-8 saat sonra başlanabilmektedir. Yarılanma ömrü uzun olduğu için, böbrek yetmezliği olan hastalarda kullanımı kontrendikedir. DMAH'lere oranla daha az çalışılmış olup, bu ajanın kullanımına ilişkin verilerin kanıt düzeyi daha düşüktür. 


\section{Asetil Salisilik Asit (ASA)}

Hem COX1 hem de COX2 sentezini baskılayan anti-inflamatuvar bir ilaçtır. COX1 inhibisyonu ile trombosit kümeleşmesi için gerekli olan tromboksan A2'yi baskılayarak antikoagülan etki gösterir. Bu etkisini 75-300 mg arasında göstermekle birlikte ortopedik cerrahi profilaksisinde $81-100 \mathrm{mg}$ arasındaki dozlarda kullanılmaktadır. 1970'li yıllarda düşük doz ASA ile profilakside iyi sonuçlar alındığı bildirilmiş; ancak daha sonraki yıllarda trombosit agregasyonunun venöz değil arteriyel dolaşımda daha önemli olduğunun kabul edilmesiyle, VTE'de ASA'nın yeri olup olmadı̆̆ı tartışıımaya başlanmıştır. Ancak, güncel çalışmalarda ASA'nın VTE'de koruyucu olarak kullanılabileceği gösterilmiştir. ${ }^{[54]}$

ASA, 2008 yılındaki ACCP kılavuzunda önerilen ajanlar arasında yer almamaktadır; fakat, 2012 ACCP kılavuzunda 1C kanıt düzeyinde önerilmektedir. ASA'nın önerilme nedeni, daha az yara yeri ve kanama komplikasyonlarına yol açmasıyla ilişkilidir. Bala ve ark.'nın yaptıkları bir çalışmada, 2007-2015 yılları arasında TDA sonrası ASA kullanımında \%30'luk bir artış saptanmıştır. ${ }^{[49]}$ Yakın zamanlı bir meta-analizde, TDA ve total kalça artroplastisi (TKA) sonrası ASA kullanan hastalarda DVT oranı \%1,2, PE oranı \%0,6, kanama oranı $\% 0,3$ olarak bulunmuştur. ${ }^{[55]}$

ABD'de ASA'nın yaygın kullanımı, günde iki kez 325 mg'dır. Parvizi ve ark.'nın VTE için standart riske sahip TDA uygulanmış hastalarda $325 \mathrm{mg}$ ile $81 \mathrm{mg}$ ASA kullanımını karşılaştırdıkları çalışmalarında, düşük doz ASA'nın VTE profilaksisinde yüksek doz kadar etkin olduğu gösterilmiştir. Ek olarak düşük dozla gastro-intestinal yakınmalar daha az olmakla birlikte kanama komplikasyonları açısından iki doz grubu arasında belirgin bir fark bulunmamıştır. ${ }^{[56]}$

\section{Direkt Oral Antikoagülanlar}

\section{Rivaroksaban}

Rivaroksaban oral olarak kullanılabilen bir direkt Faktör Xa inhibitörüdür. TDA sonrası VTE profilaksisinde kullanımı için FDA'dan (Food and Drug Administration) onay alınmıştır. illaç etkileşimleri çok azdır ve kan testleri ile doz ayarlamasına gerek yoktur. Semptomatik VTE'yi önlemedeki etkinliği ve majör kanama oranlarının DMAH'lerden belirgin bir farklııık göstermediği RECORD çalışması ile gösterilmiştir. ${ }^{[57]}$ TDA sonrasında profilaksi amaçlı 12 gün boyunca $10 \mathrm{mg}$ /gün kullanılmakta olup, yaşa ve kiloya göre dozunda değişikliğe gerek yoktur. ilk dozun ameliyattan altı ile sekiz saat sonra alınması önerilmekte olup çoğu cerrah tarafindan DMAH'lerde olduğu gibi 12. saatte başlanmaktadır.

\section{Apiksaban}

Yakın zamanda FDA tarafindan TDA ve TKA sonrası VTE profilaksisinde kullanılmak üzere onayı olan oral direkt Faktör Xa inhibitörüdür. Rivaroksabandan farklı olarak hem böbrek hem karaciğer yoluyla atılmaktadır. TDA sonrası oral yolla $2,5 \mathrm{mg} /$ gün 12 gün boyunca alınması önerilmektedir. Karaciğer yetmezliği olanlarda ve serum kreatinin seviyesi $1,5 \mathrm{mg} / \mathrm{dl}$ üzerinde olanlarda kullanılması önerilmemektedir. Profilaksi için ameliyatı izleyen 12-18 saat içinde başlanması önerilmektedir. ${ }^{[58]}$ DMAH ile karşılaştırılan çalışmalarda etkinlik ve güvenlik açısından benzer sonuçlar bulunmuştur.

Bir meta-analizde, 24.385 hastayı içeren yedi çalışma değerlendirilmiş; direkt Faktör Xa inhibitörlerinin (rivaroksaban ve apiksaban) DVT'nin önlenmesinde enoksaparine üstünlüğü gösterilmiştir. Ancak, PE gelişimi, majör kanama oluşması, yara yeri enfeksiyonu ve transfüzyon gereksinimi açısından aralarında belirgin bir fark saptanmamıştır. Son yıllarda, bu nedenlerden dolayı ve kullanım kolaylığı açısından TDA sonrası profilakside daha çok tercih edilmektedir. ${ }^{[59]}$

\section{Dabigatran}

Oral olarak alınabilen yeni keşfedilen bir direkt trombin (Faktör II) inhibitörüdür. ABD'de TDA sonrası henüz kullanılmamakta olup RE-MODEL Tip 3 faz çalışmasında VTE profilaksisinde etkin ve güvenli bir şekilde kullanılabileceği belirtilmiştir. ${ }^{[60]}$ Direkt Faktör $X$ inhibitörleri gibi çok az ilaç reaksiyonuna sahip olup kan testleri ile doz ayarlamasına gereksinim duyulmamaktadır. RE-MOBILIZE çalışmasında ise benzer kanama komplikasyonları bulunmasına rağmen, VTE sıklığında azalma belirgin olarak gösterilememiştir ve daha uzun süreli takip sonuçlarına gereksinim duyulduğu belirtilmiştir. ${ }^{[61]}$

ACCP kılavuzunda ise TDA sonrası profilaksi amaçlı 12-15 gün süresince $150 \mathrm{mg}$ /gün oral olarak alınması önerilmektedir. Ameliyattan 4 saat sonra verilmesi gerekmektedir. Kreatinin klerensi $30 \mathrm{ml} / \mathrm{dk}$ altında olan hastalarda önerilmemektedir. Dabigatran DMAH'ler ile benzer etkinlik göstermesine rağmen DMAH'lerin uzun dönem sonuçlarının daha iyi bilinmesi nedeniyle dabigatrana tercih edilmesi gerektiği belirtilmiştir. ${ }^{[3]}$

\section{TEDAVi}

\section{DVT}

Tedavide hedef; PE gelişimini önlemek, varolan trombüsün ilerlemesini durdurmak, tromboze olan 
damarların reperfüzyonunu sağlamak ve posttrombotik sendrom, tromboz nüksleri, pulmoner hipertansiyon gibi geç komplikasyonların gelişiminin engellenmesidir. Tedavi seçenekleri arasında antikoagülan tedavi, trombolitik tedavi ve inferior vena kava filtreleri yer almaktadır. Akut DVT tedavisinde antikoagülanlar verilmektedir. Trombolitik tedavi, yaygın DVT'de ya da masif PE tedavisinde kullanılmaktadır. Vena kava filtreleri, antikoagülasyon tedavisinin kontrendike olduğu akut DVT olgularında uygulanmaktadır. Tedavi akut (ilk 5-10 gün), kısa (ilk üç-altı ay) ve uzun dönem (üç-altı aydan sonrası) olmak üzere üç faza ayrılmıştır.

\section{Antikoagülan tedavi}

Antikoagülan verilmesi DVT tedavisinin temel taşıdır. Akut tedavi evresinde (ilk 5-10 gün) standart heparin, DMAH ya da fondaparinuksla parenteral tedaviye başlanıp K vitamini antagonistlerine geçilir; kısa ve uzun dönem tedavide $\mathrm{K}$ vitamini antagonistleri kullanılmaktadır. Hastanede yatırılmadan izlenen hastalarda oral antikoagülanlar da verilebilmektedir; fakat yarılanma ömürleri daha uzundur, etkilerini geri döndürmek daha zordur. Karaciğer ve böbrek yetmezliği olan hastalarda vücutta birikebilir. Akut evrede amaç, trombin ve fibrin pıhtı oluşumunun engellenmesidir. Böylelikle bulgular gerilerken trombüsün daha da büyümesi ve emboli atması önlenmiş olur. Daha yaygın bir trombüs oluşumunun önlenmesiyle fibrinolitik sistem aktive olur ve mevcut trombüsün parçalanma süreci başlar. ${ }^{[62]}$

Majör ortopedik cerrahiler, antikoagülasyon kullanımına bağlı kanama açısından yüksek riskli girişimlerdir; profilaktik dozla antikoagülasyona ameliyat sonrası 12.-24. saatte başlanması, tedavi dozuna ise 48-72 saatten önce geçilmemesi önerilmektedir. ${ }^{[62]}$

Akut tedavi evresinde hastaya bir girişim planlanacaksa standart heparin ya da DMAH uygulanması önerilmektedir. Kanama riski yüksek hastalarda, morbid obez ya da çok zayıf olanlarda, böbrek işlev bozukluğu varlığında standart heparinler kullanılmaktadır. Doz ayarlaması zorluk göstermektedir; ayrıca heparinin indüklediği trombositopeniye yol açma riski DMAH'ye göre daha yüksektir. Fondaparinuksun trombositopeniye yol açma olasılı̆̆ı daha düşük olmakla birlikte yarılanma ömrünün uzun olması (17-21 saat) bir dezavantajdır.

$\mathrm{K}$ vitamini antagonistleriyle (warfarin) tedaviye, parenteral ajanlarla terapötik kan düzeylerine ulaştıktan sonra başlanmalıdır. En az beş gün süreyle ya da INR 2'nin üstüne çıkana kadar iki tedaviye birlikte devam edilmelidir. INR değerine göre parenteral tedavi kesilerek sadece warfarinle devam edilir.
Uzun dönem tedavide amaç DVT rekürrensi ve DVT komplikasyonlarından korunmaktır. DVT'nin nedeni cerrahi gibi geçici risk faktörleriyse genellikle üç ayIık tedavi yeterlidir. Bu aşamada en sık kullanılan ilaç warfarin olmakla birlikte son yıllarda yeni çıkan oral antikoagülanlar da tedavi seçenekleri arasına girmiştir. ilk DVT atağı sonrasında hastada geçici risk faktörleri mevcut ise üç aylık profilaksi önerilir. İdiyopatik olgularda ilk atak sonrası profilaksi altı ay olmalıdır. Eğer hastada dokümante edilmiş kalıtsal trombofili yaratan bir durum varsa tedaviye en az 12 ay devam etmek gereklidir. ${ }^{[62]}$

\section{Trombolitik tedavi}

Tedavide rutin olarak sistemik trombolitik ajan kullanımının yeri yoktur. On dört günden kısa süreli semptomu olan, fonksiyonel durumu iyi olanlar ve yaşam beklentisi en az bir yıl olan hastaların dahil olduğu yaygın proksimal DVT'si bulunan ve kanama riski düşük seçilmiş hasta gruplarında kullanılmaktadır.

\section{Inferior vena kava filtreleri}

Kanama riski nedeniyle antikoagülan tedaviye başlanamayan proksimal ven trombozu olan hastalarda uygulanabilmektedir. Hastanın antikoagülasyon tedavisine kontrendikasyon oluşturan durumu geçici ise, çıkarılabilecek filtreler kullanılmalı ve hastalar yakın olarak izlenmelidir. Kontrendikasyon ortadan kalktığında filtre çıkarılıp antikoagülasyon tedavisine geçilmelidir.

\section{Pulmoner Emboli}

PE ve DVT, tek bir klinik antitenin farklı uzanımları olarak tanımladığından, masif PE olmadıkça benzer şekilde tedavi edilir.

Masif PE olgularında eğer kanama riski düşükse trombolitik tedavi önerilir. Trombolitik tedavi semptomların başlangıcından itibaren ilk 14 gün içinde etkilidir. Bu nedenle semptomların başlangıcından sonra 14 günden fazla süre geçen olgularda trombolitik tedavi uygulanması önerilmez.

Kullanılan trombolitik ilaçlar; streptokinaz, ürokinaz ve rekombinant doku plazminojen aktivatörüdür. Trombolitik tedavi kararı verildiğinde antikoagülan tedavi kesilmelidir.

Kanama riski nedeniyle trombolitik tedavi alamayan veya kritik durumu trombolitik tedavinin etkili olmasına kadar geçecek süreyi beklemeye izin vermeyen seçilmiş hastalarda girişimsel kateterizasyon teknikleri ile embolektomi ya da cerrahi pulmoner embolektomi önerilir. ${ }^{[63]}$ 


\section{SONUÇ}

VTE total diz artroplastisinin ciddi bir komplikasyonudur. Son yıllarda, profilaksinin yaygın kullanımı ile birlikte VTE görülme oranlarında ciddi düşüşler saptanmıştır. Profilaksinin amacı, olguları VTE'nin ciddi ve ölümcül bir klinik tablosu olan PE gelişiminden korumaktır. Mekanik profilaksi, farmakolojik ajanların kullanılıp kullanılmamasından bağımsız olarak mutlaka her TDA hastasına ameliyat sonrası dönemde başlanmalıdır. Farmakolojik ajanların seçiminde, etkin profilaksi beklentisinin yanında, bu ilaçlara bağlı ortaya çıkabilecek kanama komplikasyonları ve hastanın komorbid hastalıkları göz önünde bulundurulmalıdır. ASA kullanımı son yıllara kadar tartışma konusu olmakla birlikte, son ACCP kılavuzuna güçlü öneri olarak girmiştir ve standart riskli hasta grubunda kullanımı giderek yaygınlaşmaktadır. Yayımlanan kılavuzlarda hangi profilaktik ajanın en etkili ve en güvenli olduğu ile ilgili ve ideal profilaksi süresiyle ilgili öneriler yer almamaktadır.

\section{KAYNAKLAR}

1. Segal JB, Eng J, Tamariz LJ, Bass EB. Review of the Evidence on Diagnosis of Deep Venous Thrombosis and Pulmonary Embolism. Ann Fam Med 2007;5(1):63-73. Crossref

2. Shahi A, Chen AF, TanTL, Maltenfort MG, Kucukdurmaz F, Parvizi J. The incidence and economic burden of in-hospital venous thromboembolism in the United States. J Arthroplasty 2017;32(4):1063-6. Crossref

3. Falck-Ytter Y, Francis CW, Johanson NA, Curley C, Dahl OE, Schulman S, Ortel TL, Pauker SG, Colwell CW Jr. Prevention ofVTE in orthopedic surgery patients: antithrombotic therapy and prevention of thrombosis, 9th ed: American College of Chest Physicians Evidence-Based Clinical Practice Guidelines. Chest 2012;141(2 Suppl):e278S-325S. Crossref

4. Dorr LD, Gendelman V, Maheshwari AV, Boutary M, Wan Z, Long WT. Multimodal thromboprophylaxis for total hip and knee arthroplasty based on risk assessment. J Bone Joint Surg Am 2007;89(12):2648-57. Crossref

5. Hitos K, Fletcher JP. Venous thromboembolism following primary total knee arthroplasty. Int Angiol 2006;25(4):343-51.

6. Ogonda L, Hill J, Doran E, Dennison J, Stevenson M, Beverland D. Aspirin for thromboprophylaxis after primary lower limb arthroplasty: early thromboembolic events and 90 day mortality in 11,459 patients. Bone Joint J 2016;98$\mathrm{B}(3): 341-8$. Crossref

7. Lee YK, Chung CY, Koo KH, Lee KM, Ji HM, Park MS. Conflict of interest in the assessment of thromboprophylaxis after total joint arthroplasty: a systematic review. J Bone Joint Surg Am 2012;94(1):27-33. Crossref

8. Lieberman JR, Heckmann N. Venous thromboembolism prophylaxis in total hip arthroplasty and total knee arthroplasty patients: from guidelines to practice. J Am Acad Orthop Surg 2017;25(12):789-98. Crossref

9. Cooper JW, Groce J 3rd. DVT/PE prophylaxis in medically ill patients: a new avenue of clinical management in the long term care setting. Consult Pharm 2001;16(Suppl D):7-17.

10. Sharrock NE, Go G, Harpel PC, Ranawat CS, Sculco TP, Salvati EA. The John Charnley Award: Thrombogenesis during total hip arthroplasty. Clin Orthop Relat Res 1995;(319):16-27. Crossref
11. Maynard MJ, Sculco TP, Ghelman B. Progression and regression of deep vein thrombosis after total knee arthroplasty. Clin Orthop Relat Res 1991;(273):125-30. Crossref

12. Berman AT, Parmet JL, Harding SP, Israelite CL, Chandrasekaran K, Horrow JC, Singer R, Rosenberg $H$. Emboli observed with use of transesophageal echocardiography immediately after tourniquet release during total knee arthroplasty with cement. J Bone Joint Surg Am 1998;80(3):389-96. Crossref

13. Anderson FA Jr, Wheeler HB, Goldberg RJ, Hosmer DW, Patwardhan NA, Jovanovic B, Forcier A, Dalen JE. A population based perspective of the hospital incidence and case-fatality rates of deep vein thrombosis and pulmonary embolism. The Worcester DVT Study. Arch Intern Med 1991;151(5):933-8. Crossref

14. Oger E. Incidence of venous thromboembolism: A communitybased study in Western France. EPI-GETBP Study Group. Groupe d'Etude de la Thrombose de Bretagne Occidentale. Thromb Haemost 2000;83(5):657-60.

15. Caprini JA, Arcelus JI, Reyna JJ. Effective risk stratification of surgical and nonsurgical patients for venous thromboembolic disease. Semin Hematol 2001;38(2 Suppl 5):12-9. Crossref

16. Warlow C, Ogston D, Douglas AS. Venous thrombosis following strokes. Lancet 1972;299(776)4:1305-6. Crossref

17. World Health Organization Collaborative Study of Cardiovascular Disease and Steroid Hormone Contraception: Venous thromboembolism disease. Lancet 1995;346(8990):1575-82. Crossref

18. Flordal PA, Bergqvist D, Burmark US, Ljungström KG, Törngren S. Risk factors for major thromboembolism and bleeding tendency after elective general surgical operations. The Fragmin Multicentre Study Group. Eur J Surg 1996;162:783-9.

19. Samama MM. Epidemiology of risk factors of deep venous thrombosis (DVT) of the lower limbs in community practice: the SIRIUS study. Thromb Haemost 1993;69:763.

20. Heit JA, Silverstein MD, Mohr DN, Petterson TM, O'Fallon WM, Melton LJ 3rd. Risk factors for deep vein thrombosis and pulmonary embolism: A population-based case-control study. Arch Intern Med 2000;160(6):809-15. Crossref

21. Alikhan R, Cohen AT, Combe $S$, Samama MM, Desjardins L, Eldor A, Janbon C, Leizorovicz A, Olsson CG, Turpie AG. Risk factors for venous thromboembolism in hospitalized patients with acute medical illness: Analysis of the MEDENOX Study. Arch Intern Med 2004;164(9):963-8. Crossref

22. Rahr HB, Sorensen JV. Venous thromboembolism and cancer. Blood Coagul Fibrinolysis 1992;3(4):451-60. Crossref

23. Pomp ER, Rosendaal FR, Doggen CJ. Smoking increases the risk of venous thrombosis and acts synergistically with oral contraceptive use. Am J Hematol 2008;83(2):97-102. Crossref

24. Nielsen PT, Jorgensen LN, Albrecht-Beste, Leffers AM, Rasmussen LS. Lower thrombosis risk with epidural blockade in kneearthroplasty. Acta Orthop Scand 1990;61(1):29-31. Crossref

25. Lieberman JR, Huo MM, Hanway J, Salvati EA, Sculco TP, Sharrock NE. The prevalence of deep venous thrombosis after total hip arthroplasty with hypotensive epidural anesthesia. J Bone Joint Surg Am 1994;76(3):341-8. Crossref

26. Modig J, Malmberg P., Karlström G. Effect of epidural versus general anesthesia on calf blood flow. Acta Anaesthesiol Scand 1980;24(4):305-9. Crossref 
27. Sharrock NE, Go G, Williams-Russo P, Haas SB, Harpel PC. Comparison of extradural and general anaesthesia on the fibrinolytic response to total knee arthroplasty. $\mathrm{Br} \mathrm{J}$ Anaesth 1997;79(1):29-34. Crossref

28. Aglietti P, Baldini A, Vena LM, Abbate R, Fedi S, Falciani M. Effeect of tourniquet use on activation of coagulation in total knee replacement. Clin Orthop Relat Res 2000 371:169-77. Crossref

29. Fukuda A, Hasegawa M, Kato K, Shi D, Sudo A, Uchida A. Effect of tourniquet application on deep vein thrombosis after total knee arthroplasty. Arch Orthop Trauma Surg 2007;127(8):671-5. Crossref

30. Ho WK, Hankey GJ, Lee $\mathrm{CH}$, Eikelboom JW. Venous thromboembolism: diagnosis and management of deep venous thrombosis. Med J Aust 2005;182(9):476-81.

31. Bozkurt AK, Demirkılıç U, Topçuoğlu Ş, Gürbüz A, Yazıcıoğlu L, Küçüker SA. Periferik Arter ve Ven Hastalıkları Tedavi Kılavuzu. Türk Kalp Damar Cerrahisi Derneği. Ankara: Öncü Basımevi; 2008

32. Geerts WH, Pineo GF, Heit JA, Bergqvist D, Lassen MR, Colwell CW, Ray JG. Prevention of venous thromboembolism: the Seventh ACCP Conference on Antithrombotic and Thrombolytic Therapy. Chest 2004;126(3):338S-400S. Crossref

33. Goodacre S, Sampson F, Thomas S, van Beek E, Sutton A. Systematic review and metaanalysis of the diagnostic accuracy of ultrasonography for deep vein thrombosis. BMC Med Imaging 2005;5:6. Crossref

34. Watanabe $H$, Sekiya $H$, Kariya $Y$, Hoshino $Y$, Sugimoto $H$, Hayasaka $S$. The incidence of venous thromboembolism before and after total knee arthroplasty using 16-row multidetector computed tomography. J Arthroplasty 2011;26(8):1488-93. Crossref

35. Fraser DG, Moody AR, Morgan PS, Martel AL, Davidson I. Diagnosis of lower-limb deep venous thrombosis: a prospective blinded study of magnetic resonance direct thrombus imaging. Ann Intern Med 2002;136(2):89-98. Crossref

36. Wells PS, Anderson DR, Rodger M, Stiell I, Dreyer JF, Barnes D, Forgie M, Kovacs G, Ward J, Kovacs MJ. Excluding pulmonary embolism at the bedside without diagnostic imaging: management of patients with suspected pulmonary embolism presenting to the emergency department by using a simple clinical model and d-dimer. Ann Intern Med 2001;135(2):98-107. Crossref

37. Janku GV, Paiement GD, Green HD. Prevention of venous thromboembolism in orthopaedics in the United States. Clin Orthop Relat Res 1996;(325):313-21. Crossref

38. Mont MA, Jacobs JJ, Boggio LN, Bozic KJ, Della Valle CJ, Goodman SB, Lewis CG, Yates AJ Jr, Watters WC 3rd, Turkelson CM, Wies JL, Donnelly P, Patel N, Sluka P. Preventing venous thrombo embolic disease in patients undergoing elective hip and knee arthroplasty. J Am Acad Orthop Surg 2011;19(12):768-76. Crossref

39. Westrich $\mathrm{GH}$, Sculco TP. Prophylaxis against deep venous thrombosis after total knee arthroplasty. Pneumatic plantar compression and aspirin compared with aspirin alone. J Bone Joint Surg Am 1996;78(6):826-34. Crossref

40. Zimlich RH, Fulbright BM, Friedman RJ. Current status of anticoagulation therapy after total hip and total knee arthroplasty.J Am Acad Orthop Surg 1996;4(1):54-62. Crossref

41. Williams HR, MacDonald DA. Thromboprophylaxis in lower limb arthroplasty surgery: a review. Curr Orthop 1997;11(1):19-23. Crossref

42. Bottner F, Sculco TP. Nonpharmacologic thromboembolic prophylaxis in total knee arthroplasty. Clin Orthop Relat Res 2001;392:249-56. Crossref
43. Hamilton WG, Reeves JD, Fricka KB, Goyal N, Engh GA, Parks NL. Mechanical thromboembolic prophylaxis with risk stratification in total knee arthroplasty. J Arthroplasty 2015;30(1):43-5. Crossref

44. Pierce TP, Cherian JJ, Jauregui JJ, Elmallah RK, Lieberman JR, Mont MA. A current review of mechanical compression and its role in venous thromboembolic prophylaxis in total knee and total hip arthroplasty. J Arthroplasty 2015;30(12):227984. Crossref

45. Snyder MA, Sympson AN, Scheuerman CM, Gregg JL, Hussain LR. Efficacy in deep vein thrombosis prevention with extended mechanical compression device therapy and prophylactic aspirin following total knee arthroplasty: a randomized control trial. J Arthroplasty 2017;32(5):147882. Crossref

46. Turpie AG, Lassen MR, Davidson BL, Bauer KA, Gent M, Kwong LM, Cushner FD, Lotke PA, Berkowitz SD, Bandel TJ, Benson A, Misselwitz F, Fisher WD; RECORD4 Investigators. Rivaroxaban versus enoxaparin for thromboprophylaxis after total knee arthroplasty (RECORD4): a randomised trial. Lancet 2009;373(9676):1673-80. Crossref

47. Colwell CW Jr, Froimson MI, Anseth SD, Giori NJ, Hamilton WG, Barrack RL, Buehler KC, Mont MA, Padgett DE, Pulido PA, Barnes CL. A mobile compression device for thrombosis prevention in hip and knee arthroplasty. J Bone Joint Surg Am 2014;96(3):177-83. Crossref

48. Colwell CW Jr, Froimson MI, Mont MA, Ritter MA, Trousdale RT, Buehler KC, Spitzer A, Donaldson TK, Padgett DE. Thrombosis prevention after total hip arthroplasty: A prospective, randomized trial comparing a mobile compression device with low-molecular-weight heparin. J Bone Joint Surg Am 2010;92(3):527-35. Crossref

49. Cafri G, Paxton EW, Chen Y, Cheetham CT, Gould MK, Sluggett J, Bini SA, Khatod M. Comparative effectiveness and safety of drug prophylaxis for prevention of venous thromboembolism after total knee arthroplasty. J Arthroplasty 2017;32(11):3524-8, e1. Crossref

50. Bala A, Huddleston JI III, Goodman SB, Maloney WJ, Amanatullah DF. Venous thromboembolism prophylaxis after TKA. aspirin, warfarin, enoxaparin, or factor Xa inhibitors? Clin Orthop Relat Res 2017;475(9):2205-13. Crossref

51. Comp PC, Spiro TE, Friedman RJ, Whitsett TL, Johnson GJ, Gardiner GA, Landon GC, Jové M. Prolonged enoxaparin therapy to prevent venous thromboembolism after primary hip or knee replacement. J Bone Joint Surg Am 2001;83(3):33645. Crossref

52. He Z, Morrissey H, Ball P. Review of current evidence available for guiding optimal Enoxaparin prophylactic dosing strategies in obese patients -Actual Weight-based vs Fixed. Crit Rev Oncol Hematol 2017;113:191-4. Crossref

53. Suen K, Westh RN, Churilov L, Hardidge AJ. LowMolecular-Weight Heparin and the Relative Risk of Surgical Site Bleeding Complications: Results of a Systematic Review and Meta-Analysis of Randomized Controlled Trials of Venous Thromboprophylaxis in Patients After Total Joint Arthroplasty. J Arthroplasty 2017;32(9):2911-9. Crossref

54. Gutowski CJ, Zmistowski BM, Lonner JH, Purtill JJ, Parvizi J. Direct costs of aspirin versus warfarin for venous thromboembolism prophylaxis after total knee or hip arthroplasty. J Arthroplasty 2015;30(9 Suppl):36-8. Crossref

55. An WG, Phan K, Levy YD, Bruce WJM. Aspirin as thromboprophylaxis in hip and knee arthroplasty: a systematic review and metaanalysis. J Arthroplasty 2016;31(11):260816. Crossref 
56. Feldstein MJ, Low SL, Chen AF, Woodward LA, Hozack WJ. A comparison of two dosing regimens of ASA following total hip and knee arthroplasties. J Arthroplasty 2017;32(9):S15761. Crossref

57. Lassen MR, Ageno W, Borris LC, Lieberman JR, Rosencher N, Bandel TJ, Misselwitz F, Turpie AGG; RECORD-3 Investigators. Rivaroxaban versus enoxaparin for thromboprophylaxis after total knee arthroplasty. N Engl J Med 2008;358(26):277686. Crossref

58. Lassen MR, Raskob GE, Gallus A, Pineo G, Chen D, Hornick $P$; ADVANCE-2 investigators. Apixaban versus enoxaparin for thromboprophylaxis after knee replacement (ADVANCE-2): a randomised double-blind trial. Lancet 2010;375(9717):80715. Crossref

59. Russell RD, Huo MH. Apixaban and rivaroxaban decrease deep venous thrombosis but not other complications after total hip and total knee arthroplasty. J Arthroplasty 2013;28(9):1477-81. Crossref
60. Eriksson BI, Dahl OE, Rosencher N, Kurth AA, van Dijk CN, Frostick SP, Kälebo P, Christiansen AV, Hantel S, Hettiarachchi R, Schnee J, Büller HR; RE-MODEL Study Group. Oral dabigatran etexilate vs. subcutaneous enoxaparin for the prevention of venous thromboembolism after total knee replacement: the REMODEL randomized trial. J Thromb Haemost 2007;5(11):217885. Crossref

61. Ginsberg JS, Davidson BL, Comp PC Francis CW, Friedman RJ, Huo MH, Lieberman JR, Muntz JE, Raskob GE, Clements ML, Hantel S, Schnee JM, Caprini JA; RE-MOBILIZE Writing Committee. Oral thrombin inhibitor dabigatran etexilate vs North American enoxaparin regimen for prevention of venous thromboembolism after knee arthroplasty surgery. J Arthroplasty 2009;24(1):1-9. Crossref

62. Streiff MB, Agnelli G, Connors JM, Crowther M, Eichinger S, Lopes R, McBane RD, Moll S, Ansell J. Guidance for the treatment of deep vein thrombosis and pulmonary embolism. J Thromb Thrombolysis 2016;41(1):32-67. Crossref

63. Vishal S, Mehta N, Rawat N, Lehrman SG, Aronow WS. Management of massive and nonmassive pulmonary embolism. Arch Med Sci 2012;6:957-69. Crossref 